\author{
ACTA MYCOLOGICA \\ Vol. 44 (1): 19-27 \\ 2009
}

\title{
Association of water-borne conidial fungi with epiphytic tree fern (Drynaria quercifolia)
}

\author{
KISHORE S. KARAMCHAND and KANDIKERE R. SRIDHAR
}

Microbiology and Biotechnology, Department of Biosciences

Mangalore University, Mangalagangotri, Mangalore IN-574-199, sirikr@yahoo.com

Karamchand K. S., Sridhar K. R.: Association of water-borne conidial fungi with epiphytic tree fern (Drynaria quercifolia). Acta Mycol. 44 (1): 19-27, 2009.

The live and dead tissues, and trapped leaf litter by the epiphytic tree fern Drynaria quercifolia associated with riparian tree species of Konaje (west coast) and Sampaje (Western Ghat) streams of India during dry (summer) and wet (monsoon) seasons yielded 37 species of water-borne conidial fungi on bubble chamber incubation. Dead bracket leaves of fern possess the highest species as well as conidia in Konaje, while the trapped leaf litter in Sampaje. During summer, the diversity was highest in bracket leaves in both locations, while in monsoon season it was highest in rhizomes of Konaje and in trapped leaf litter in Sampaje. Even though the conidial output from tissues of Drynaria and trapped leaf litter were not equivalent to stream submerged leaf litter, the species richness ranged between $40 \%$ and $75 \%$ in Konaje and Sampaje streams. As stable epiphyte, Drynaria exposed to wet and dry regimes in tree canopies of west coast and Western Ghats likely to serve as host for perfect states of water-borne hyphomycetes.

Key words: water-borne hyphomycetes, diversity, conidia, canopy, Drynaria, epiphyte, tree fern

\section{INTRODUCTION}

Aquatic hyphomycetes (also known as 'freshwater fungi' and 'Ingoldian fungi') are phylogenetically heterogeneous group dominant on submerged leaf litter in streams (Bärlocher 1992). In addition to aquatic hyphomycetes, aero-aquatic hyphomycetes are also known from dead plant litter in streams (e.g., helicosporus fungi). Aquatic hyphomycetes produce conidia with three basic shapes (conventional, sigmoid and multiradiate) (Ingold 1942, 1975a; Goos 1987), while helicosporus fungal spores are twisted at least up to $180^{\circ}$ (Goos 1987). The sigmoid and multiradiate shapes of aquatic hyphomycetes are the product of convergent evolution for adaptation in flowing waters (Ingold 1975b). Helicosporus fungi also showed convergent lineages and their spores evolved for dispersion in water by trapping air-bubbles (Zhao et al. 2007). Aquatic hyphomycetes and helicosporus fungi have been connected to their 
perfect states by conventional (Webster, Descals 1979; Goos 1987; Webster 1992; Sivichai, Jones 2003; Zhao et al. 2007) and molecular techniques (Belliveau, Bärlocher 2005; Campbell et al. 2006; Tsui, Barbee 2006).

Besides aquatic habitats, water-borne hyphomycetes are also known from terrestrial habitats (e.g., soil, leaf litter, roots, leaf surfaces) (Sridhar, Bärlocher 1993; Bärlocher 2006). Forest canopies represent a broad group of fungi (e.g. endophytic, pathogenic, phylloplane and lignicolous fungi (Lodge, Cantrell 1995). Water-borne hyphomycetes are also common in tree canopies such as throughfall, stemflow, tree holes and epiphytes of temperate regions) (Canada, Hungary, Japan and Poland) (Bandoni 1981; Ando, Tubaki 1984; Czeczuga, Orłowska 1998; Gönczöl, Révay 2006). Recently, they have also been reported from the epiphytic fern and tree holes in India (Sridhar et al. 2006; Karamchand, Sridhar 2008). Heavy rainfall (350-650 cm/annum) during southwest monsoon (during June-September) results in continuous wet conditions in tree canopies of the Western Ghats and west coast of Southern India. It is likely such canopies support the growth, sporulation and dissemination of water-borne hyphomycetes. Tree ferns with their overlapping fronds access nutrients from stem flow, through fall and drips, and serve as 'trash baskets'. The tree fern Drynaria quercifolia, also known as 'oak-leaf basket fern' is a dominant fern in Western Ghats and west coast of India. Their bracket leaves serve as natural funnels to trap canopy debris (e.g. flowers, dead bark, dead leaves). In view of a few studies on water-borne hyphomycetes in tree canopies in tropics (Sridhar et al. 2006; Karamchand, Sridhar 2008), the present study aims at evaluating their assemblage and diversity in D. quercifolia associated with riparian trees of the west coast and Western Ghat region during summer and monsoon seasons.

\section{MATERIALS AND METHODS}

Five riparian trees species along the Konaje stream ( $90 \mathrm{~m}$ a.s.l.; $\left.12^{\circ} 48^{\prime} \mathrm{N}, 74^{\circ} 55^{\prime} \mathrm{E}\right)$ of the west coast and Sampaje stream (510 m a.s.l.; $\left.12^{\circ} 29^{\prime} \mathrm{N}, 75^{\circ} 35^{\prime} \mathrm{E}\right)$ of the Western Ghats associated with Drynaria quercifolia (Linn.) J. Sm. (Polypodiaceae) were chosen for the study. This tree fern produces two kinds of leaves: nest leaves (slender, fragile, short-lived, turn brown on senescence and shed on drying with persistent rachis) and bracket leaves (tough, leathery, resembling oak leaves, remain attached to creeping rhizome during senescence and dried condition, and decay in standing dead position). The distance between the stream and trees sampled was between 2 and $50 \mathrm{~m}$, while the height at which the fern attached to trees was between 2 and 20 m. During February (summer) and July (monsoon) 2006, from each fern, pieces of rhizome with roots, partially skeletonized bracket leaves and trapped leaf litter were sampled in sterile polythene bags and transferred to the laboratory.

Randomly excised tissues (5-6 leaf and rhizome pieces, $1 \times 2.5 \mathrm{~cm}$; $15-20$ small root pieces) were rinsed in water to eliminate surface debris, suspended in sterile distilled water in five replicates (each in $250 \mathrm{ml}$ Erlenmeyer flask) and bubbled through Pasteur pipette using aquarium aerators $\left(48 \mathrm{hr}, 23 \pm 2^{\circ} \mathrm{C}\right)$. Aerated water was filtered (Millipore filters, $5 \mu \mathrm{m}$ ), stained with $0.1 \%$ cotton blue in lactophenol and enumerated the liberated conidia from each substrate and calculated the conidial 
output per gram dry mass of substrate. The mean conidia produced by each fungus per mg dry mass were also calculated:

Mean conidia/fungus $/ \mathrm{mg}$ dry mass $=($ Total conidia liberated $/ \mathrm{mg}) \div($ Total species recorded)

The Simpson ( $\left.D^{\prime}\right)$ and Shannon $\left(H^{\prime}\right)$ diversities (Magurran 1988) in each substrate were estimated:

Simpson's index: $D^{\prime}=1 \div \sum(p i)^{2}$

Shannon index: $H^{\prime}=-\sum$ (pi ln pi)

(where, $p i$ is the proportion of fungal species $i$ contributes to the total).

The evenness $\left(J^{\prime}\right)$ fungi in different substrates (Pielou 1975) were expressed:

$J^{\prime}=H^{\prime} \div H^{\prime} \max$

(where $H^{\prime}$ max is the maximum value of diversity for the number of fungal species present).

Percent Jaccard's index of similarity $(J I)$ was calculated for the fungi colonized in different substrates pair-wise (Kenkel, Booth 1992):

$\mathrm{JI}(\%)=(\mathrm{c}) \div(\mathrm{a}+\mathrm{b}+\mathrm{c}) \times 100$

(where, $c$ is the number of fungal species occurring in both substrates, $a$ is the number of fungal species unique to the first substrate and $b$ is the number of fungal species unique to the second substrate).

Paired t-test was employed to assess the difference in conidial output from different substrates between summer and monsoon seasons (parameters: $P$ value, two tailed; confidence interval, 95\%) (StatSoft 2008).

\section{RESULTS AND DISCUSSION}

A total of 24 species of water-borne hyphomycetes was associated with tissues of Drynaria and trapped leaf litter in Konaje region (Tab. 1). The species richness was

\section{Table 1}

Water-borne hyphomycetes (conidia/g dry mass) recovered from tissues of Drynaria and trapped leaf litter in riparian trees of Konaje region during summer and monsoon (in parenthesis) (mean, $\mathrm{n}=5$ ) (different letters across the total conidia of each substrate between summer and monsoon indicate significant difference; $P<0.05$; paited $t$-test)

\begin{tabular}{|l|c|c|c|c|}
\hline \multicolumn{1}{|c|}{ Species } & $\begin{array}{c}\text { Bracket } \\
\text { leaf }\end{array}$ & Root & Rhizome & $\begin{array}{c}\text { Trapped } \\
\text { leaf }\end{array}$ \\
\hline Anguillospora crassa Ingold & $56(7)$ & $63(6)$ & $4(6)$ & 5 \\
\hline A. longissima (Sacc. \& P. Syd.) Ingold & $301(7)$ & $83(16)$ & $(17)$ & $2(638)$ \\
\hline Arborispora sp. & $5(5)$ & & & $(8)$ \\
\hline Campylospora chaetocladia Ranzoni & 18 & & & $(103)$ \\
\hline Clathrosphaerina zalewskii Beverw. & & & $(7)$ & \\
\hline Cylindorcarpon sp. & 20 & 153 & 10 & $1(8)$ \\
\hline Flabellospora crassa Alas. & 42 & & & \\
\hline F. verticillata Alas. & & 5 & $(3)$ & 1 \\
\hline F. multiradiata Nawawi & & & $(3)$ & \\
\hline Flagellospora curvula Ingold & 319 & 17 & & $78(218)$ \\
\hline
\end{tabular}


Tab. 1. cont.

\begin{tabular}{|l|c|c|c|c|}
\hline F. penicillioides Ingold & 723 & & 2 & 4 \\
\hline Helicosporium sp. & 8 & & & \\
\hline Lunulospora curvula Ingold & & $(2)$ & & \\
\hline Magdalaenaea monogramma G. Arnaud & & & & $(29)$ \\
\hline Phalangispora constricta Nawawi \& J. Webster & & $(2)$ & & \\
\hline Retiarius bovicornutus D.L. Olivier & 8 & & & 1 \\
\hline Tetracladium marchalianum De Wild. & $(5)$ & & & \\
\hline Tricladium malaysianum Nawawi & 18 & $5(2)$ & $(1)$ & 3 \\
\hline Trinacrium subtile Riess & 208 & & & \\
\hline Tripospermum infalcatum K. Ando \& Tubaki & 8 & & & \\
\hline Triscelophorus acuminatus Nawawi & $36(100)$ & $13(4)$ & $(7)$ & $2(144)$ \\
\hline T. konajensis K.R. Sridhar \& Kaver. & $8(39)$ & $5(2)$ & $(3)$ & $3(284)$ \\
\hline T. monosporus Ingold & $(3)$ & $(2)$ & & \\
\hline Tumularia aquatica (Ingold) Descals \& Marvanová & & $(2)$ & $(3)$ & \\
\hline Total species & $15(7)$ & $8(9)$ & $3(9)$ & $10(8)$ \\
\hline Cumulative species & $15(7)$ & $16(11)$ & $(16) 14$ & $16(18)$ \\
\hline Total conidia/g dry mass & $1778^{\mathrm{a}}$ & $344^{\mathrm{a}}\left(38^{\mathrm{b}}\right)$ & $16^{\mathrm{a}}\left(50^{\mathrm{a}}\right)$ & $100^{\mathrm{a}}$ \\
& $\left(166^{\mathrm{b}}\right)$ & & & $\left(1432^{\mathrm{b}}\right)$ \\
\hline
\end{tabular}
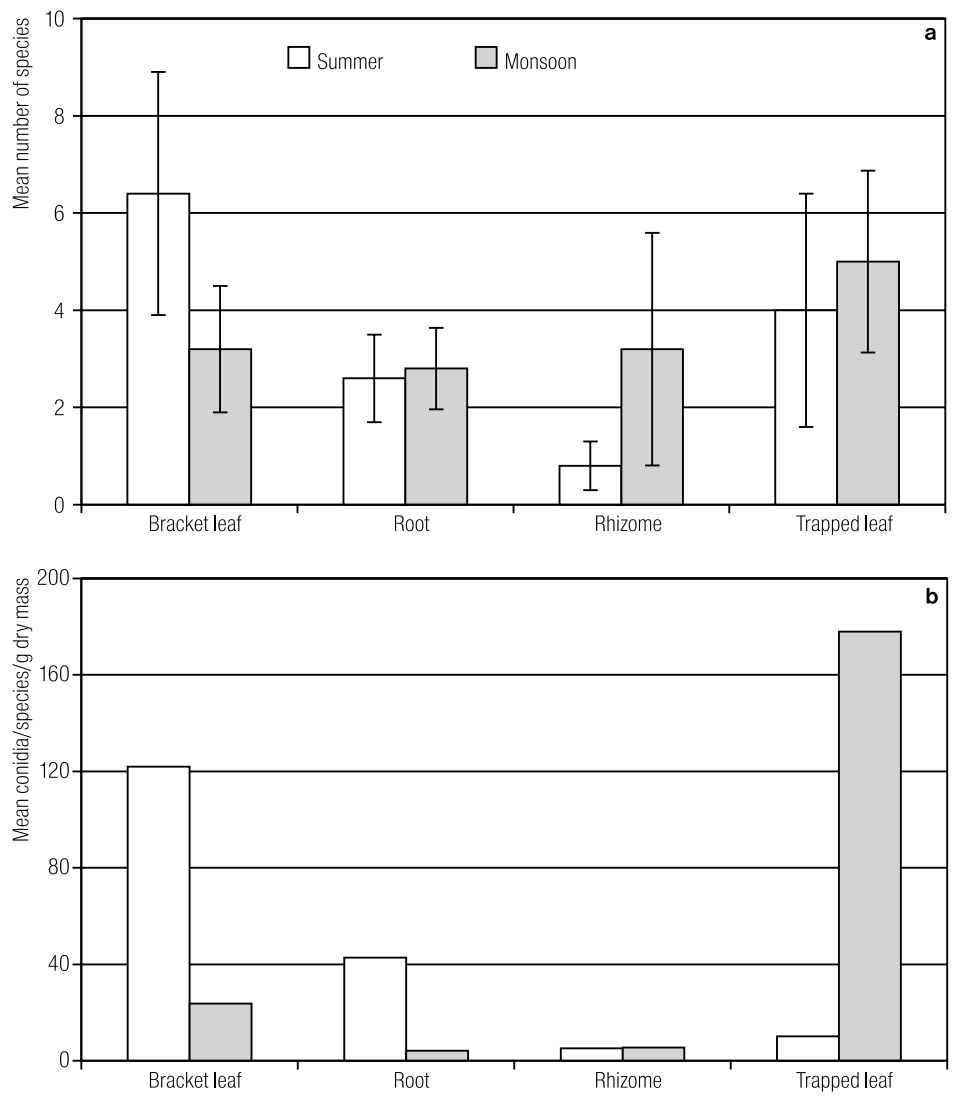

Fig. 1. Mean number of species $(\mathrm{a})(\mathrm{n}=5$, mean \pm SD) and mean conidia $(\mathrm{n}=5)$ per species per gram dry mass (b) of bracket leaf, root, rhizome (Drynaria quercifolia) and trapped leaf litter of Konaje region. 
Table 2

Water-borne hyphomycetes (conidia/g dry mass) recovered from tissues of Drynaria and trapped leaf litter in riparian trees of Sampaje region during summer and monsoon (in parenthesis) (mean, $\mathrm{n}=5$ ) (same letters across the total conidia of each substrate between summer and monsoon indicate no significant difference; $P>0.05$; paired $t$-test)

\begin{tabular}{|c|c|c|c|c|}
\hline Species & $\begin{array}{c}\text { Bracket } \\
\text { leaf }\end{array}$ & Root & Rhizome & $\begin{array}{c}\text { Trapped } \\
\text { leaf }\end{array}$ \\
\hline Anguillospora crassa Ingold & $(5)$ & $(12)$ & & $36(5)$ \\
\hline A. longissima (Sacc. \& P. Syd.) Ingold & $7(8)$ & $176(9)$ & 12 & $192(11)$ \\
\hline Campylospora chaetocladia Ranzoni & & & & $(2)$ \\
\hline Clavariopsis aquatica De Wild. & & & (1) & (23) \\
\hline C. azlanii Nawawi & (2) & & & (2) \\
\hline Clavatospora tentacula Sv. Nilsson & & & & $(2)$ \\
\hline Cylindorcarpon sp. & 7 & 2 & 2 & $35(3)$ \\
\hline Flabellospora crassa Alas. & & & & 2 \\
\hline Flagellospora curvula Ingold & $2(2)$ & 2 & & $42(12)$ \\
\hline F. penicillioides Ingold & & 92 & 13 & \\
\hline Helicomyces louisianensis Goos & & & & (2) \\
\hline H. roesus Link & & & & (2) \\
\hline Isthmotricladia gombakiensis Nawawi & & & (6) & \\
\hline Lateriramulosa quadriradiata K. Mirua \& Okano & & & & 6 \\
\hline Lunulospora curvula Ingold & & 5 & 2 & \\
\hline L. cymbiformis K. Miura & & (3) & & \\
\hline Phalangispora constricta Nawawi \& J. Webster & & & & 1 \\
\hline Speiropsis pedatospora Tubaki & & 3 & & 6 \\
\hline Titaea clarkeae Ellis \& Everh. & & & & 5 \\
\hline Trinacrium subtile Riess & 5 & 3 & & 1 \\
\hline Tripospermum myrti (Lind) S. Hughes & 2 & & & 26 \\
\hline Triscelophorus acuminatus Nawawi & $4(6)$ & 4 & (8) & (21) \\
\hline T. konajensis K.R. Sridhar \& Kaver. & 2 & & $4(26)$ & $3(8)$ \\
\hline T. monosporus Ingold & & & & (2) \\
\hline Trisulcosporium acerinum H.J. Huds. \& B. Sutton & & & & 4 \\
\hline Varicosporium elodeae W. Kegel & & & & 1 \\
\hline $\begin{array}{l}\text { Volucrispora graminea Ingold, P.J. McDougall \& } \\
\text { Dann }\end{array}$ & & & & 3 \\
\hline Total species & $7(5)$ & $8(3)$ & $5(4)$ & $15(13)$ \\
\hline Cumulative species & $7(5)$ & $10(6)$ & $10(9)$ & $18(15)$ \\
\hline Total conidia/g dry mass & $29^{\mathrm{a}}\left(23^{\mathrm{a}}\right)$ & $287^{\mathrm{a}}\left(24^{\mathrm{a}}\right)$ & $33^{\mathrm{a}}\left(41^{\mathrm{a}}\right)$ & $363^{\mathrm{a}}\left(95^{\mathrm{a}}\right)$ \\
\hline
\end{tabular}

highest in bracket leaves and lowest in rhizomes (15 vs. 3 species) during summer. The conidial output was peaked in bracket leaves and lowest in rhizomes during summer (1778 vs. 16/g). The cumulative species between substrates of Drynaria and trapped leaves was more or less constant during summer (15-16), while it steadily increased during monsoon (7-18) (Tab. 1). The mean number of species and mean conidia per species were highest in bracket leaves in summer followed by trapped leaves in monsoon (Fig. 1). Tissues of Drynaria and trapped leaves of Sampaje region yielded 27 species (Tab. 2). The trapped leaves possess highest number of species during summer as well as monsoon (15 vs. 13 species) (Tab. 2). The total conidial output was highest in trapped leaves during summer $(363 / \mathrm{g})$. The cumulative species between substrates of Drynaria and trapped leaves was steadly increased in monsoon (7-18) as well as summer (5-15) seasons. The mean conidial output per species was highest in roots during summer (Fig. 2). Significant difference (paired $t$-test) in conidial out put was seen between summer and monsoon in bracket leaves $(P=0.0319)$, roots $(P=0.0424)$ and trapped leaves $(P=0.0336)$ in Konaje region, while there was no significant difference in Sampaje region. The fungal diversity was 

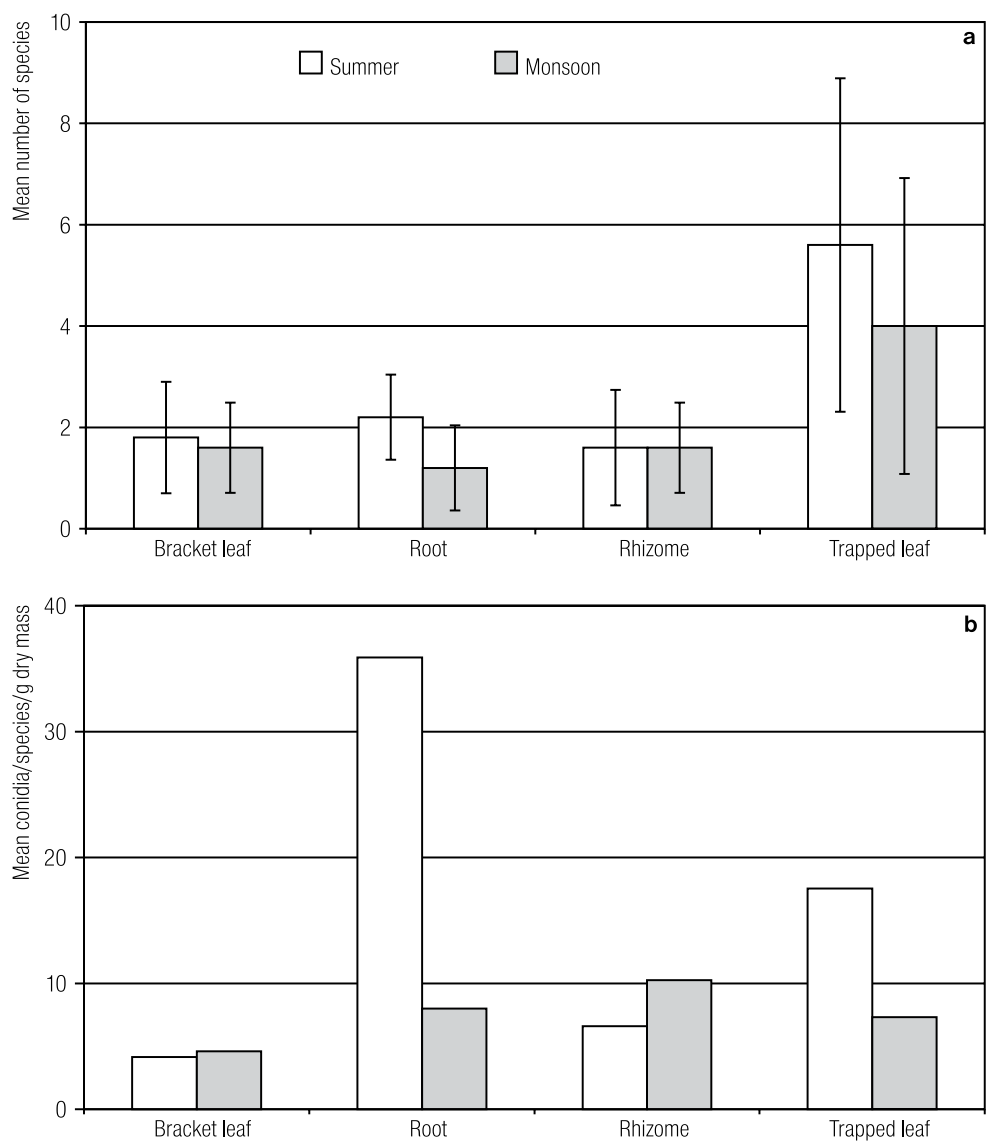

Fig. 2. Mean number of species $(a)(n=5$, mean \pm SD) and mean conidia $(n=5)$ per species per gram dry mass (b) of bracket leaf, root, rhizome (Drynaria quercifolia) and trapped leaf litter of Sampaje region.

Table 3

Diversity and evenness of water-borne hyphomycetes in tissues of Drynaria and trapped leaves during summer and monsoon (in parenthesis) in Konaje and Sampaje regions

\begin{tabular}{|l|c|c|c|c|}
\hline \multirow{2}{*}{ Tissue } & \multicolumn{2}{c|}{ Diversity } & \multicolumn{2}{c|}{ Evenness } \\
\cline { 2 - 5 } & Simpson & Shannon & Simpson & Shannon \\
\hline \multicolumn{5}{|c|}{ Konaje } \\
\hline Bracket leaf & $0.758(0.580)$ & $2.538(1.726)$ & $0.812(0.672)$ & $0.650(0.615)$ \\
\hline Root & $0.701(0.719)$ & $2.110(2.629)$ & $0.798(0.867)$ & $0.703(0.829)$ \\
\hline Rhizome & $0.567(0.833)$ & $1.299(2.777)$ & $0.800(0.919)$ & $0.819(0.876)$ \\
\hline Trapped leaf & $0.388(0.724)$ & $1.410(2.200)$ & $0.427(0.827)$ & $0.424(0.733)$ \\
\hline \multicolumn{5}{|c|}{ Sampaje } \\
\hline Bracket leaf & $0.850(0.783)$ & $2.620(2.127)$ & $0.958(0.938)$ & $0.933(0.916)$ \\
\hline Root & $0.522(0.620)$ & $1.384(1.406)$ & $0.595(0.891)$ & $0.461(0.877)$ \\
\hline Rhizome & $0.712(0.551)$ & $1.919(1.413)$ & $0.864(0.717)$ & $0.827(0.707)$ \\
\hline Trapped leaf & $0.683(0.859)$ & $2.353(3.099)$ & $0.730(0.921)$ & $0.602(0.838)$ \\
\hline
\end{tabular}


Table 4

Jaccard's similarity index (\%) of bracket leaf, root, rhizome and trapped leaf of Drynaria of Konaje and Sampaje (in parenthesis) regions

\begin{tabular}{|c|c|c|c|}
\hline & Root & Rhizome & Trapped leaf \\
\hline Bracket leaf & $38(46)$ & $35(31)$ & $53(39)$ \\
\hline & Root & $53(39)$ & $50(29)$ \\
\hline & & Rhizome & $42(19)$ \\
\hline
\end{tabular}

highest in bracket leaves of Drynaria in Konaje and Sampaje regions during summer season (Tab. 3). During monsoon, the diversity was highest in rhizome of Konaje, while in trapped leaf litter of Sampaje. The Jaccard's similarity index revealed 35\% to $53 \%$ between the substrates in Konaje, while it was less similar (19-46\%) in Sampaje (Tab. 4).

Live and dead parts of forest tree canopies accommodate a variety of fungi. Although extensive studies have been conducted on species composition and ecological functions of water-borne fungi in woodland streams, their vertical distribution and ecological significance in riparian tree canopies is not clearly understood. These fungi are at risk due to unidirectional flow of water in streams and they overcome their extinction through colonizing the stationary substrates in stream column and along the stream banks (e.g., wood, riparian roots). Similarly, tree canopy substrates (e.g., leaves, bark) and habitats (e.g., tree holes, epiphytes) serve as potential shelter for these fungi. The role of conidial fungi in canopy of Douglas fir constitute a guild and serve as intermediaries of energy flow similar to aquatic hyphomycetes in stream habitats (Carroll 1981).

The current study demonstrated that the dead or live tissues of Drynaria and trapped leaf litter in riparian trees are potential substrates for colonization of waterborne hyphomycetes. These fungi may persist in canopy during summer and perpetuate in rainy season as evident in dry leaves on the stream banks (Sanders, Webster 1978; Sridhar, Kaveriappa 1987). The live rhizome of Drynaria in Konaje and Sampaje region yielded relatively lowest number of fungi suggests that water-borne hyphomycetes exist in rhizome as endophytes or epiphytes as suggested by Gönczöl and Révay (2003). Recently, four water-borne hyphomycetes (Dwayaangam colodena, Retiarius sp., Tripospermum camelopardus and T. myrti) were endophytic in black spruce (Picea mariana) needles in a mixed wood forest of Canada indicating their role as endophytes in tree canopies (Sokolski et al. 2006). The roots of Drynaria screened in our study were partially live, thus, the number of species and conidial output were fewer than those found in dead bracket leaves or trapped leaves. The overall conidial output from tissues of Drynaria and trapped leaf litter although not equivalent to stream leaf litter, it is comparable to the dry leaf litter on stream banks (Sridhar, Bärlocher 1993) and the species richness was between 40\% (Konaje stream) and $75 \%$ (Sampaje stream). Except for rhizome, the conidial output in rest of the substrates showed significant difference between summer and monsoon in Konaje, but it was not so in Sampaje possibly due to cooler conditions.

Arborispora sp. with its characteristic multiradiate conidia was common in intact leaves, stem flow, through fall and tree snow (Ando 1992). Trinacrium spp. are also primarily known from rain waters, stem flow, through fall and tree holes (Ando 1992; Gönczöl, Révay 2003, 2004). Tripospermum spp. sporulated abundantly on 
live leaves and more prevalent in tree canopies (Ando 1992; Gönczöl, Révay 2004). The majority of spores found in the tree canopies are multiradiate (Gönczöl, Révay 2006; Sridhar et al. 2006). These conidia might have adapted to canopy habitats and their branches may resist total removal from the leaf or bark surface. However, in our study, fungi with sigmoid conidia were also common (e.g., Anguillospora crassa and $A$. longissima). Among the helicosporus fungi, Helicomyces spp. and Helicosporium sp. were rare in tree canopies. Out of 37 fungi recorded in our study, up to 21 are known from the tropical tree canopies (Sridhar et al. 2006; Karamchand, Sridhar 2008) and the rest constitute new records (e.g., Clavariopsis aquatica, C. azlanii, Clathrosphaerina zalewaskii, Helicomyces louisianensis, Magdalaenaea monogramma, Speiropsis pedatospora, Lateriramulosa quadriradiata, Titaea clarkeae, Tetracladium marchalianum, Tricladium malaysianum, Trisulcosporium acerinum and Tumularia aquatica).

Sexual states of many aquatic hyphomycetes have been reported on plant detritus from terrestrial habitats in the proximity of streams (Webster 1992). Webster (1992) and Shearer (1992) opined that wood in terrestrial habitats and emergent portions of riparian vegetation consists of teleomorphs of water-borne hyphomycetes. It is likely the perfect state of fungi might exist in tree canopies as well and disseminate their asexual propagules to streams through aerosols, raindrops and stemflow. Bandoni (1981) predicted that conidia of fungi produced in tree canopies transferred directly into streams. As the bracket leaves and rachis of nest leaves of Drynaria persists even after their death on the tree canopies, further observations of dead tissues may reveal perfect states of water-borne hyphomycetes.

Acknowledgements. Authors are indebted to Mangalore University for granting permission to carry out this study at the Department of Biosciences. One of us (KSK) acknowledges the research fellowship granted under SC/ST Cell, Mangalore University and Rajeev Gandhi Fellowship, University Grants Commission, New Delhi. We thank B.S. Kadamannaya for travel and field assistance.

\section{REFERENCES}

Ando K. 1992. A study of terrestrial aquatic hyphomycetes. Trans. Mycol. Soc. Japan 33: 415-425.

Ando K., Tubaki K. 1984. Some undescribed hyphomycetes in the rain drops from intact leaf-surface. Trans. Mycol. Soc. Japan 25: 21-37.

Bärlocher F. 1992. The Ecology of Aquatic Hyphomycetes. Springer-Verlag, Berlin.

Bärlocher F. 2006. Fungal endophytes in submerged roots. (In:) B. Schulz, C. Boyle, T. Sieber (eds). Microbial Root Endophytes. Springer-Verlag, Berlin and New York: 179ñ190.

Bandoni R.J. 1981. Aquatic hyphomycetes from terrestrial litter. (In:) D.T. Wicklow, G.C. Carroll (eds). The Fungal Community - Its Organization and Role in the Ecosystem, Marcel Dekker, New York: 693-708.

Belliveau M.J.-R., Bärlocher F. 2005. Molecular evidence confirms multiple origins of aquatic hyphomycetes. Mycol. Res. 109: 1407-1417.

Campbell J., Shearer C., Marvanová L. 2006. Evolutionary relationships among aquatic anamorphs and teleomorphs: Lemonniera, Margaritispora and Goniopila. Mycol. Res. 110: 1025-1033.

Carroll G.C. 1981. Mycological inputs to ecosystem analysis. (In:) Wicklow D.T., G.C. Carroll (eds). The Fungal Community - Its Organization and Role in Ecosystem, Marcel Dekker, New York: 25-35.

Czeczuga B., Orłowska M. 1998. Hyphomycetes in rain water draining from intact trees. Roczniki Akademii Medycznej w Białymstoku 43: 66-84.

Gönczöl J., Révay Á. 2003. Treehole fungal communities: aquatic, aero-aquatic and dematiaceous hyphomycetes. Fungal Diversity 12: 19-24. 
Gönczöl J., Révay, Á. 2004. Fungal spores in rainwater: stemflow, throughfall and gutter conidial assemblages. Fungal Diversity 16: 67-86.

Gönczöl J., Révay Á. 2006. Species diversity of rainborne hyphomycete conidia from living trees. Fungal Diversity 22: 37-54.

Goos R.D. 1987. Fungi with a twist: The helicosporus hyphomycetes. Mycologia 79: 1-22.

Ingold C.T. 1942. Aquatic hyphomycetes of decaying alder leaves. Trans. Br. Mycol. Soc. 25: 339-417.

Ingold C.T. 1975a. An illustrated guide to aquatic and waterborne hyphomycetes (Fungi Imperfecti). Freshwater Biological Association Scientific Publication 30, United Kingdom.

Ingold C.T. 1975b. Convergent evolution in aquatic fungi: the tetraradiate spore. Bot. J. Linn. Soc. 7: $1-25$.

Karamchand K. S., Sridhar, K. R. 2008. Water-borne conidial fungi inhabiting tree holes of the west coast and Western Ghats of India. Czech Mycology 60: 63-74.

Kenkel N.C., Booth T. 1992. Multivariate analysis in fungal ecology. (In:) G.C. Carroll, D.T. Wicklow (eds). The Fungal Community: Its Organization and Role in the Ecosystem, Dekker, New York: 209-227.

Lodge D., Cantrell S. 1995. Fungal communities in wet tropical variation in time and space. Can. J. Bot. 73: 1391-1398.

Magurran A.E. 1988. Ecological Diversity and its Measurement. Princeton University Press, New Jersey.

Pielou F.D. 1975. Ecological Diversity. Wiley InterScience, New York.

Sanders P.F., Webster J. 1978. Survival of aquatic hyphomycetes in terrestrial situations. Trans. Br. Mycol. Soc. 71: 231-237.

Shearer C.A. 1992. The role of woody debris. (In:) F. Bärlocher (ed.). The Ecology of Aquatic Hyphomycetes, Springer-Verlag, Berlin: 77-98.

Sivichai S., Jones E.B.G. 2003. Teleomorphic-anamorphic connections of freshwater fungi. (In:) C. K. M. Tsui, K. D. Hyde (eds). Freshwater Mycology, Fungal Diversity, Series 10: 259-272.

Sokolski S., Piché Y., Chauvet E., Bérubé J.A. 2006. A fungal endophyte of black spruce (Picea mariana) needles is also an aquatic hyphomycete. Mol. Ecol. 15: 1955-1962.

Sridhar K. R., Bärlocher F. 1993. Aquatic hyphomycetes on leaf litter in and near a stream in Nova Scotia, Canada. Mycol. Res. 97: 1530-1535.

Sridhar K. R., Kaveriappa K.M. 1987. Occurrence and survival of aquatic hyphomycetes in terrestrial conditions. Trans. Br. Mycol. Soc. 89: 606-609.

Sridhar K.R., Karamchand K.S., Bhat R. 2006. Arboreal water-borne hyphomycetes with oak-leaf basket fern Drynaria quercifolia. Sydowia 58: 309-320.

StatSoft 2008. Statistica, Version 8. Statsoft, Tulsa, Oklahoma.

Tsui C.K.M., Berbee M.L. 2006. Phylogenetic relationships and convergence of helicosporus fungi inferred from ribosomal DNA sequences. Mol. Phylogen. Evol. 39: 587-597.

Webster J. 1992. Anamorph-teleomorph relationships. (In:) F. Bärlocher (ed.). The Ecology of Aquatic Hyphomycetes. Springer-Verlag, Berlin: 99-117.

Webster J., Descals E. 1979. The teleomorphs of water-borne hyphomycetes from freshwater. (In:) B. Kendrick (ed.). The Whole Fungus. National Museums of Canada, Ottawa: 419-447.

Zhao G.Z., Liu X.Z., Wu W.P. 2007. Helicosporus hyphomycetes from China. Fungal Diversity 26: 313524. 